\title{
GLUCOSE-6-PHOSPHATE DEHYDROGENASE AND GLUTATHIONE REDUCTASE ACTIVITY IN METHEMOGLOBIN REDUCTION BY METHYLENE BLUE AND CYSTAMINE. STUDY ON GLUCOSE-6-PHOSPHATE DEHYDROGENASE-DEFICIENT INDIVIDUALS, ON NORMAI SUBJECTS AND ON RIBOFLAVIN-TREATED SUBJECTS.
}

\author{
Beguedio MaRRAVIERA (1", Paulo Edurdo de Abreu MACHADG(2), Domingos Alves MEIRA(3), Paulo Roberto

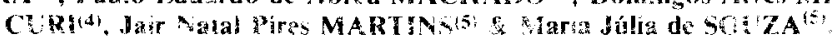

\begin{abstract}
SUMMAR I
The authors have standardized methods for evaluation of the activity of the glucose-6-phosphate dehydrogenase and of glutathione reductase. The genera! principle of the first method was based on methemoglobin formation by sodium nirrite followed by stimulation of the glucose-6-phosphate dehydrogenase with methylene blue. Forty six aublts (23 males and 23 females) were studied Subjects were not G6PD deficient and were aged 20 to 30 years. The resulis showed that methemoglobin reduction by methylene blue was 154.40 and $139.90 \mu \mathrm{g} / \mathrm{min}$ $(p<0.05)$ for males and females, respectively, in whole blood, and 221.10 and 207.85 $\mu \mathrm{g} / \mathrm{min}$ (n.s.), respectively. in washed red cells. These data showed that using washed red cells and $0.7 \mathrm{~g} \%$ sodium nitrite concentration produced no differences between sexes and also shortened reading time for the residual amount of methemcglobin to 90 minutes.

Glutathione reductase activity was evaluated on the basis of the fact that cystamine (a thiol agent) binds to the SH groups of hemoglobin, forming complexes. These complexes are reversed by the action of glutathione reductase, with methemoglobin reduction occurring simultaneousty with this reaction. Thirty two adults (16 males and 16 females) were studied. Subjects were not G6PD defícient and were aged 20 to 30 years. Methemoglobin reduction by cystamine was 81.27 and $91.13 \mu \mathrm{g} / \mathrm{min}(\mathrm{p}<0.01)$ for males and females, respectively. These data showed that using washed red cells and $0.1 \mathrm{M}$ cystamine concentration permits a reading of the residual amount of methemoglobin at 180 minutes of incubation.
\end{abstract}

Research supported by CNPq (Nos 40.3705/82 and 40.0755/85).

(1) Professor Assistente Doutor do Departamento de Moléstias Infecciosas e Parasitárias, Dermatologia e Radiologia da Faculdade de Medicina de Botucatu (UNESP). Botucatu, São Paulo, Brasil

2) Prolesson Titular do Departamento de Clinica Médica da Faculdade de Medicina de Botucatu (UNESP), Botucatu. São Paulo, Brasil.

(3) Professor Titular do Departamento de Moléstias Infecciosas e Parasitárias, Dermatologia e Radiologia da Faculdade de Medicina de Botucatu (UNESP), Boiucatu, São Paulo, Brasil.

4) Professor Adjunto do Departamento de Cirurgia e Ortopedia da Faculdade de Medicina de Botucatu (bNESP), Botucatu, São Paulo, Brasil.

(5) Técnicos do Laboratório de Moléstias Infecciosas e Parasitárias da Faculdade de Medicina de Botucatu (UNESP) Botucatu, São Paulo, Brasil.

Adtress for correspondence: Benedito Barraviera, Facuidade de Medicina de Botucatu, Universidade Estadua Paulista "Julio de Mesquita Filho", (UNESP). Caixa Posıal 576. CEP 18610 Botucatu, SP, Brasil. 
BARRAVIERA, B.; MACHADO, P.E. de A; MEIRA, D.A.; CURI, P.R.; MARTINS, J.N.P. \& SOUZA. J.M. de - Gilucose-6-phosphate dehydrogenase and glutathione reductase activity in methemoglobin reduction by methylene blue and cystamine. Study on glucose-6-phosphate dehydrogenase-deficient individuals, on normal subjects and on riboflavin-treated subjects. Rev. Inst. Med. trop. São Paulo, 30(5):370-378, 1988.

Glutathione reductase activity was evaluated by methemoglobin reduction by cystamine in 14 females before and after treatment with $10 \mathrm{mg}$ riboflavin per day for 8 days. The results were 73.69 and $94.26 \mu \mathrm{g} / \mathrm{min}(\mathrm{p}<0.01)$ before and after treatment, showing that riboflavin treatment increase glutathione reductase activity even in normal individuals.

Three Black G6PD-deficient individuals ( 2 males and 1 female) were also studied. The G6PD and glutathione reductase were partially activated, the change being more intense in males. On the basis of race and of the laboratory characteristics observed, it is possible to suggest that the G6PD deficiency of these individuals is of the African type and that the female is heterozygous for this deficiency.

Analysis of the results as a whole permitted us to conclude that the methods proposed here were efficient tor evaluating the activity of the glucose-6-phosphate dehydrogenase and of glutathione reductase. The latter is dependent on the pentose pathway, which generates NADPH, and on riboflavin, a FAD precursor vitamin.

KEY WORDS: Glucose-6-phosphate dehydrogenase; Glutathione reductase; Methemoglobin; Cystamine, Riboflavin.

\section{INTRODUCTION}

Hemoglobin, the main component of erythrocytes, can be oxidized by sodium nitrite to methemoglobin 1,2,3,10,15. In turn, methemoglobin is again reduced to hemoglobin through the metabolic pathways of glucose. Among these pathways, the pentose pathway is responsible for $17 \%$ methemoglobin reduction, $12 \%$ of which by the action of glutathione reductase 12 and $5 \%$ through NADPHdependent methemoglobin reductase 6,12 .

The pentose pathway, whose first enzyme is glucose-6-phosphate dehydrogenase (G6PD), can be stimulated by various drugs, among them methylene blue, which can increase its activity up to 40 -fold ${ }^{14}$. On the basis of these observations, BREWER et al10 proposed a method for the determination of G6PD deficiency based on artificial methemoglobin formation by sodium nitrite followed by stimulation of the pentose pathway with methylene blue in the presence of glucose. In non-G6PD-deficient individuals, the methemoglobin thus formed is reduced to hemoglobin $6,10,12$.

On the other hand, the main function of glutathione reductase inside red blood cells is to maintain the integrity of the SH-reactive groups of the hemoglobin molecule. In this respect, thiol agents, among them cystamine $\left(\mathrm{NH}_{2} \mathrm{CH}_{2}\right.$
$\mathrm{CH}_{2} \mathrm{SSCH}_{2} \mathrm{CH}_{2} \mathrm{NH}_{2}$ ), have the ability to bind to the $\mathrm{SH}$ groups located on the beta chains of the hemoglobin molecule, forming complexes 8.9 . These complexes are reversed by the action of glutathione reductase ${ }^{8,9}$. In this reaction, oxidized glutathione is formed and is again transformed to reduced glutathione through the NADPH supplied by the pentose pathway ${ }^{6.12}$. Since G6PD and 6-phosphogluconate-dehydrogenase are enzymes that reduce NADP + to NADPH, the consumption of electrons and of hydrogen ions supplied by this coenzyme, indirectly stimulates the pentose pathway.

Glutathione reductase activity can be increased by the addition of flavin-adeninedinucleotide (FAD) to the medium. This coenzyme, a riboflavin derivative, is formed in the erythrocyte from riboflavin phosphorylation $7,12,13,16,17,19$. The ingestion of $5 \mathrm{mg}$ riboflavin per day by normal individuals causes a significant increase in glutathione reductase activity 7,19

Thus, the objectives of the present study were to standardize methods for the evaluation of the activity of glucose-6-phosphate dehydrogenase through methemoglobin reduction by methylene blue, and for the evaluation of glutathione reductase activity and riboflavin deficiency through methemoglobin reduction by cystamine in G6PD-deficient patients, in normal individuals and in riboflavin-treated subjects. 
BARRAVIERA, B.; MACHADO, P.E. de A.; MEIRA, D.A.; CURI, P.R.; MARTINS, J.N.P. \& SOUZA, J.M. de -- Glucose-6-phosphate dehydrogenase and glutathione reductase activity in methemoglobin reduction by methylene blue and cystamine. Study on glucose-6-phosphate dehydrogenase-deficient individuals, on nornal subjects and on riboflavin-treated subjects. Rev. Inst. Med. trop. São Paulo, 30(5):370-378, 1988.

\section{MATERIAL AND METHODS}

\section{Evaluation of the activity of the G6PD.}

To standardize this method, we studied 46 normal, no-G6PD-deficient individuals $(23$ males and 23 females) aged 20 to 30 years. Each subject was first tested for G6PD deficiency by the method for BREWER et al10. Blood was collected into heparinized tubes and each laboratory procedure performed before incubation on a water bath at $37^{\circ} \mathrm{C}$ was carried out on an lee bach ai $4 \% \mathrm{C}$.

To determine the ideal amount of sodium nitrite, whole blood from 4 adults $(2$ males and 2 females) was used. Ten $\mu l 5 \%$ glucose, $10 \mu l$ $0.015 \%$ methylene blue and $10 \mu l$ sodium nitrite at concentration from 0.1 to $2.0 \mathrm{~g} \%$ were added to each $200 \mu \mathrm{l}$ of whole blood. The control consisted of the same procedure, but with no methylene blue added. The material was incubated on a water bath at $37^{\circ} \mathrm{C}$ for 180 minutes. Hemolysis was obtained by adding 2 drops of $2 \%$ saponin, and $10 \mathrm{ml}$ phosphate buffer (34.6 g $\mathrm{KH}_{2} \mathrm{PO}_{4}, 36.1 \mathrm{~g} \quad \mathrm{Na}_{2} \mathrm{HPO}_{4}$, $\left.12,500 \mathrm{ml} \mathrm{H} \mathrm{H}_{2} \mathrm{O}\right)$, pH 6.8 was added for reading with a double-beam spectrophotometer according to the method of EVELYN \& MALLOY1!.

Methemoglobin reduction $(\mu \mathrm{g} / \mathrm{min})$ by methylene blue was calculated by the following equation:

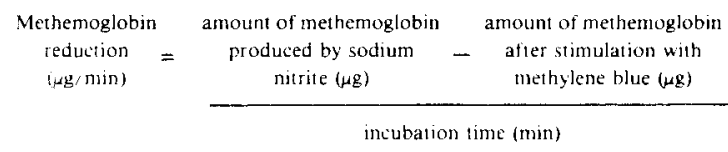

The ideal time of incubation was tested for whole blood and for washed red cells to evaluate the effect of plasma on the amount of methemoglobin produced by sodium nitrite and reduced by methylene blue. The study was conducted on 2 individuals, a male and a female, who had participated in the previous experiment.

Red cells were washed by centrifuging whole blood at $1500 \mathrm{rpm}$ for 10 minutes. The supernatant was aspirated and red cells were resuspended in gluco-physiologic solution (5.0 $\mathrm{g}$ glucose, $0.9 \mathrm{~g} \mathrm{NaCl}$, and $100 \mathrm{ml} \mathrm{H}_{2} \mathrm{O}$ ), the entire procedure being repeated three times. Finally, red cells were resuspended in Tris buffer $(6.057 \mathrm{~g}$ Tris, $2.922 \mathrm{~g} \mathrm{NaCl}, 0.9 \mathrm{~g}$ glucose, and $1000 \mathrm{ml} \mathrm{H}_{2} \mathrm{O}, \mathrm{pH} 7.45$ ) at a $1: 1$ ratio. The tests were performed using $0.7 \mathrm{~g} \%$ sodium nitrite concentration, with the material being submitted to hemolysis after 15 minutes of incubation.

Normal values for the method were standardized by studying 42 individuals ( 21 males and 21 females), using $0.7 \mathrm{~g} \%$ sodium nitrite concentration and with the material being submitted to hemolysis after 90 minutes of incubation on a water bath at $37^{\circ} \mathrm{C}$. Twelve individuals of the 42 who participated in the standardization of whole blood (6 males and 6 females) were studied for washed red cells. using $0.7 \mathrm{~g} \sigma_{0}$ sodium nitrite concentration and with the material being submitted to hemolysis after 90 minutes of incubation.

\section{Evaluation of glutathione reductase activity.}

Ideal cystamine concentration and ideal incubation time were studied in 6 normal non-G6PD-deficient white individuals $(3$ males and 3 females) aged 20 to 30 years. Two hundred $\mu \mathrm{l}$ of washed red cells, $10 \mu \mathrm{l} 0.7 \mathrm{~g} \%$ sodium nitrite, $10 \mu \mathrm{l} 5 \%$ glucose and $20 \mu \mathrm{l}$ of a 0.02 to $0.7 \mathrm{M}$ cystamine solution were used. A control containing no cystamine was performed simultaneously. The material was incubated on a water bath at $37^{\circ} \mathrm{C}$ and submitted to hemolysis at $60,120,180$ and 240 minutes of inculation. Phosphate buffer $(10 \mathrm{ml})$ was added and a reading was obtained with a doublebeam spectrophotometer. Methemoglobin reduction by cystamine was calculated as described for methylene blue.

To standardize the norml values for the method, 26 normal non-G6PD-deficient white individuals ( 13 males and 13 females) aged 20 to 30 years were studied. The cystamine concentration used was $0.1 \mathrm{M}$ and the material was submitted to hemolysis after 180 minutes of incubation on a water bath at $37^{\circ} \mathrm{C}$.

Application of the standardized methods to normal individuals treated with riboflavin and to G6PD-deficient individuals.

Ninety one individuals from the general population of Anhembi (State of São Paulo Brasil), were studied. Fourteen adult females from this group were offered treatment with 10 $\mathrm{mg}$ oral riboflavin for 10 days. This selection was made because 2 of these women had shown altered methemoglobin reduction by 
BARRAVIERA, B.; MACHADO, P.E. de A.; MEIRA, D.A.; CURI, P.R.; MARTINS, J.N.P. \& SOUZA, J.M. de - Glucose-6-phosphate dehydrogenase and glutathione reductase activity in methemoglobin reduction by methylene blue and cystamine. Study on glucose-6-phosphate dehydrogenase-deficient individuals, on normal subjects and on riboflavin-treated subjects. Rev. Inst. Med. trop. São Paulo, 30(5):370-378, 1988.

cystamine. Methemoglobin reduction by methylene blue and by cystamine was evaluated before and after treatment.

Three Black individuals showing a positive BREWER et al 10 test for G6PD deficiency were also investigated. Two were males aged 24 and 45 years, and one was a 28 -year old female.

\section{Statistical analysis}

Data were analysed statistically using the ttest for comparison of two means (Tables 1 and 2). Dependence between two variables was determined by regression analysis (grade 2 polynomial regression, Figure 1). Adjusted equations and the coefficient of determination $r^{2}$ were determined.

\section{RESULTS}

\section{Evaluation of G6PD activity.}

The evaluation of the ideal sodium nitrite concentration and of the ideal incubation time is shown in Figures 1 and 2 . The standardization of the normal values for the method is shown in Table 1 . Hematocrit values in whole blood were $46.7 \%$ and $42.47 \%$ for males and females, respectively, and hemoglobin levels were $14.44 \mathrm{~g} \%$ and $12.45 \mathrm{~g} \%$, respectively.

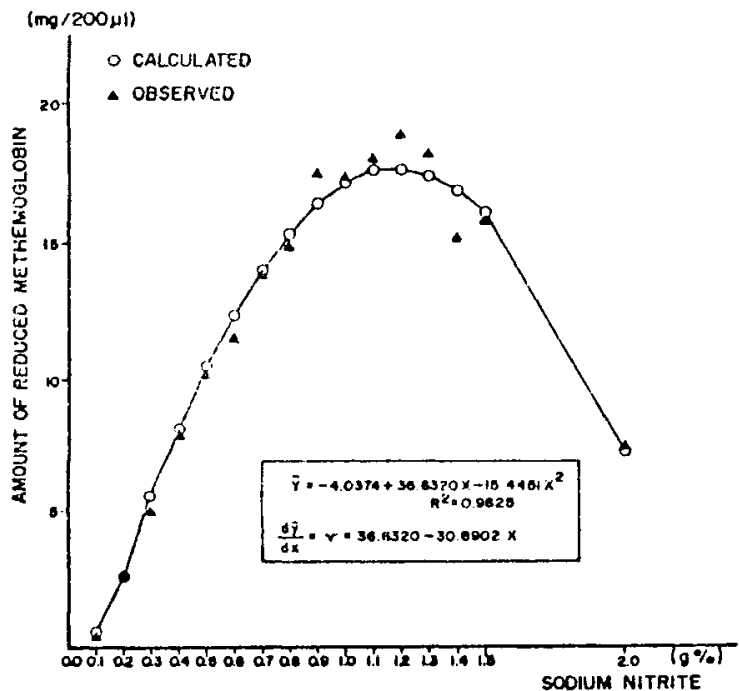

Fig. 1 - Evaluation of the ideal concentration of sodium nitrite as a function of the amount of hemoglobin reduced by methylene blue in whole blood from 4 individuals.
In washed red cells, hematocrit values were $48.50 \%$ and $43.0 \%$ and hemoglobin levels were $15.10 \mathrm{~g} \%$ and $12.83 \mathrm{~g} \%$ for males and females, respectively.

\section{Evaluation of glutathione reductase activity.}

The evaluation of the ideal cystamine concentration and ideal incubation ime is shown in Figure 3. The standardization of the normal values for the method is shown in Table 2. Hematocrit values were $49.84 \%$ and $44.46 \%$ for males and females, respectively, and hemoglobin levels were $15.82 \mathrm{~g} \%$ and 14.12 g\%, respectively.

\section{Application of the standardized methods to normal individuals treated with riboflavin and to G6PD-deficient individuals.}

The results are reported in Table 2 and 3 . It should be pointed out that 2 of the 14 subjects treated with riboflavin showed rates of methemoglobin reduction by cystamine of 46.94 $\mu \mathrm{g} / \mathrm{min}$ and $44.38 \mu \mathrm{g} / \mathrm{min}$ before treatment. These values became normal ( 100.00 and 80.05 $\mu \mathrm{g} / \mathrm{min}$, respectively) after treatment.

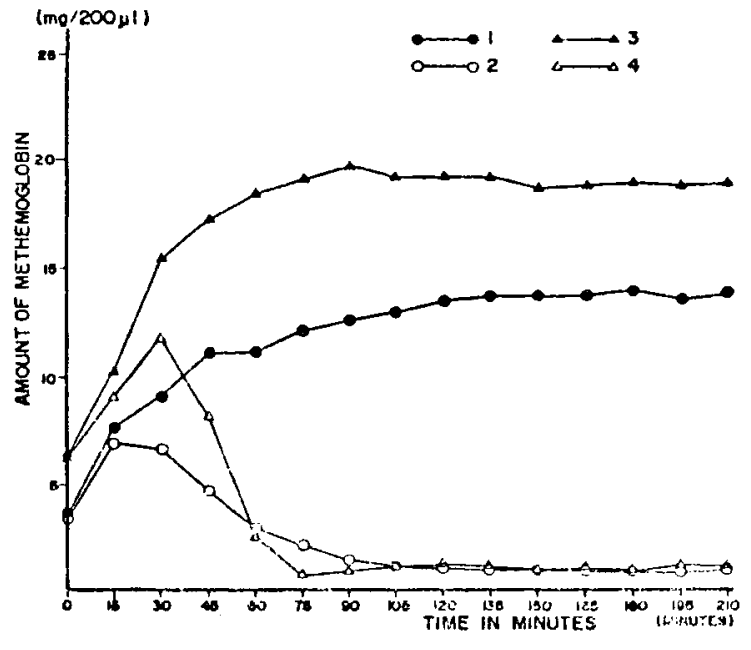

Fig. 2 - Kinetics of methemoglobin formation by sodium nitrite in whole blood (1) and washed red cells (3) and of methemoglobin reduction by methylene blue in whole blood (2) and in washed red cells (4). 
BARRAVIERA, B; MACHADO, P.E. de A.; MEIRA, D.A.; CURI, P.R.; MARTINS, J.N.P. \& SOUZA, J.M. de - Glucose-6-phosphate dehydrogenase and glutathione reductase activity in methemoglobin reduction by methylene blue and cystamine. Study on glucose-6-phosphate dehydrogenase-deficient individuals, on normal subjects and on riboflavin-treated subjects. Rev. Inst. Med. trop. São Paulo, 3015):370-378, 1988.

\section{TABLE 1}

Distribution of methemogiobin amount and methemoglobin reduction by methylene blue in the whole blood of 42 normal individuals and in the washed red cells of 12 normal individuals, by sex.

Results are reported as means \pm SD. Data were analysed statistically by the $t$ test $(\mathrm{p}<0.001): \mathrm{A} 1<\mathrm{A} 2 ; \mathrm{C} 1<\mathrm{C} 2 ; \mathrm{A} 3<\mathrm{A} 4 ; \mathrm{B} 3<\mathrm{B} 4 ; \mathrm{C} 3<\mathrm{C} 4$ $(\mathrm{p}<0.05): \mathrm{A} 1>\mathrm{A} 3 ; \mathrm{C} 1>\mathrm{C} 3$

\begin{tabular}{|c|c|c|c|c|}
\hline \multirow[b]{2}{*}{ SEX } & & \multicolumn{2}{|c|}{ AMOUNT OF METHEMOGLOBIN (mg/200 $\mu 1)$} & \multirow{2}{*}{$\begin{array}{l}\text { METHEMOGLOBIN } \\
\text { REDUCTION }(\mu \mathrm{g} \text { min }) \\
\text { (C) }\end{array}$} \\
\hline & & $\begin{array}{l}\text { SODIUM NITRITE } \\
\text { (A) }\end{array}$ & $\begin{array}{l}\text { METHYLENE BLUE } \\
\text { (B) }\end{array}$ & \\
\hline \multirow{4}{*}{ Males } & $\begin{array}{c}\text { Whole blood (1) } \\
\qquad N=21\end{array}$ & $15.21 \pm$ & $1.31 \pm$ & $154.40 \pm$ \\
\hline & & & & \\
\hline & Washed red cells (2) & $20.93 \pm$ & $1.03 \pm$ & $221.10 \pm$ \\
\hline & $N=6$ & 2.14 & 0.40 & 21.06 \\
\hline \multirow{4}{*}{ Females } & Whole blood (3) & $14.10 \pm$ & $1.48 \pm$ & $139.90 \pm$ \\
\hline & $\mathrm{N}=21$ & 1. 28 & 0.50 & 11.92 \\
\hline & Washed red cells (4) & $19.62 \pm$ & $0.92 \pm$ & $207.85 \pm$ \\
\hline & $\mathrm{N}=6$ & 2.49 & 0.14 & 28.08 \\
\hline
\end{tabular}

\section{TABLE 2}

Distribution of methemoglobin amount and methemoglobin reduction by cystamine in the washed red cells of 26 normal individuals and in 14 female subjects from Anhembi (State of São Paulo) before and after treatment with riboflavin.

Results are reported as means $\pm \mathrm{SD}$. Data were analysed statistically by the $t$ test $(\mathrm{p}<0.01): \mathrm{A} 1<\mathrm{A} 2 ; \mathrm{C} 1<\mathrm{C} 2 ; \mathrm{A} 3<\mathrm{A} 4 ; \mathrm{C} 3<\mathrm{C} 4$

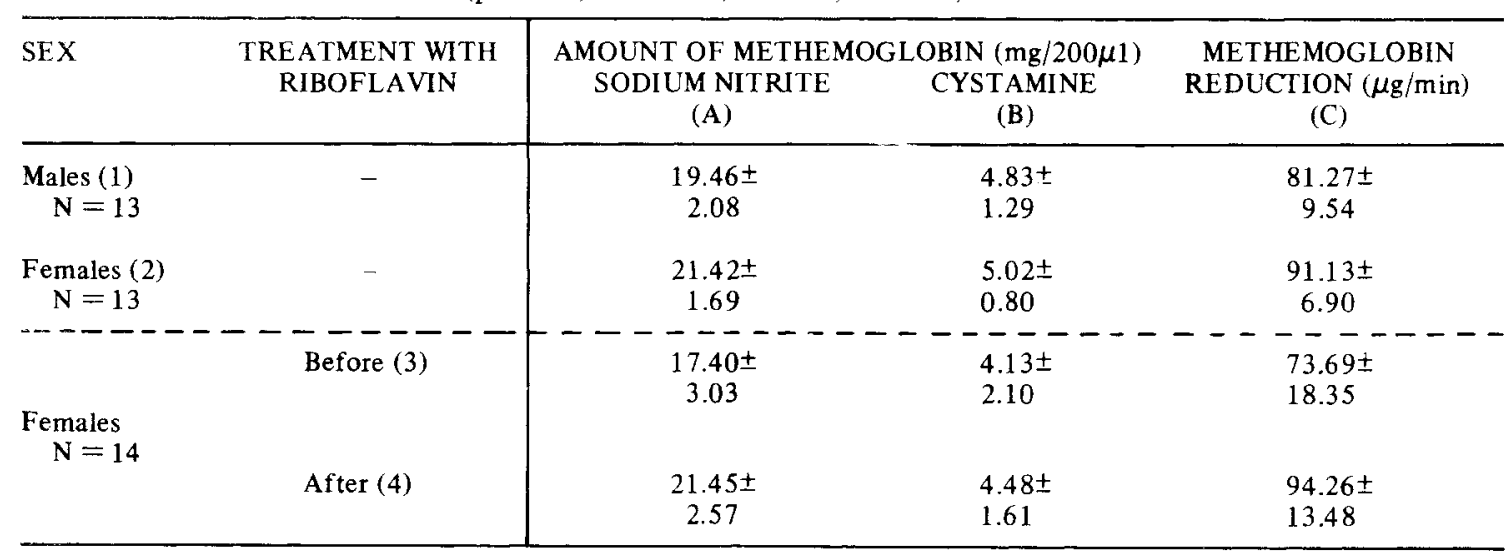

TABLE 3

Evaluation of methemoglobin reduction by methylene blue and cystamine in three G6PD-deficient adults (two males and one female).

\begin{tabular}{|c|c|c|}
\hline \multirow[t]{2}{*}{ SEX } & \multicolumn{2}{|c|}{ METHEMOGLOBIN REDUCTION $(\mu \mathrm{g} / \mathrm{min})$} \\
\hline & METHYLENE BLUE & CYSTAMINE \\
\hline \multirow[t]{2}{*}{ MALES } & 40.66 & 11.27 \\
\hline & 45.67 & 25.94 \\
\hline----- & ------- & ------ \\
\hline FEMALE & 119.11 & 45.94 \\
\hline
\end{tabular}

\section{DISCUSSION}

The method of methemoglobin reduction described by BREWER et al ${ }^{10}$ has been used as a screening test to detect G6PD-deficient individuals $\mathbf{s}^{1,2,3}$. This method, however, does not always permit an exact interpretation of the results because the G6PD gene, which is located on the $\mathrm{X}$ chromosome, causes the female genotype to be manifested in two manners, i.e. as a homozygote or a heterozygote. This 
BARRAVIERA, B.; MACHADO, P.E. de A.; MEIRA, D.A.; CURI, P.R.; MARTINS, J.N.P. \& SOUZA, J.M. de - Glucose-6-phosphate dehydrogenase and glutathione reductase activity in methemoglobin reduction by methylene blue and cystamine. Study on glucose-6-phosphate dehydrogenase-deficient individuals, on normal subjects and on riboflavin-treated subjects. Rev. Inst. Med. trop. São Paulo, 30(5):370-378, 1988.

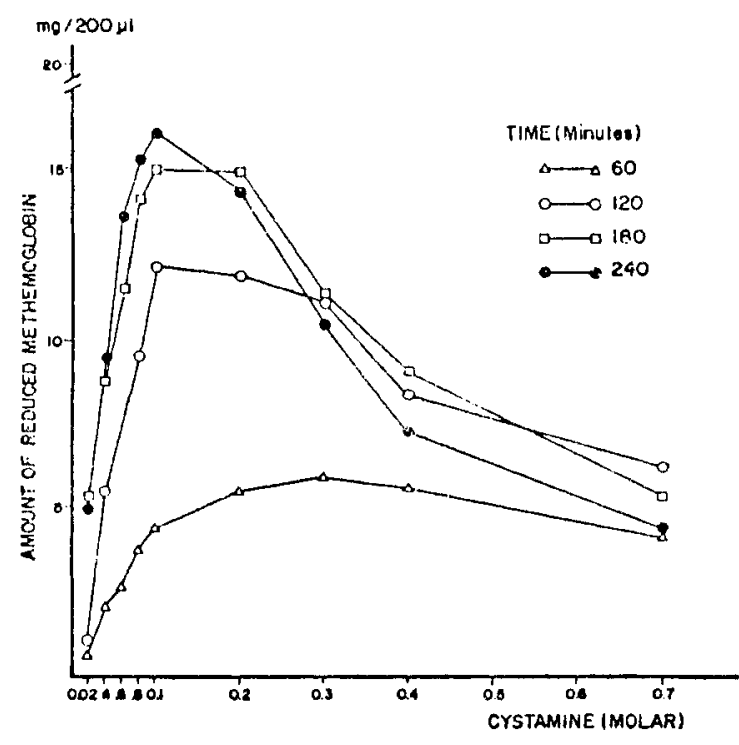

Fig. 3 - Evaluation of the ideal concentration of cystamine in washed red cells from 6 normal individuals on the basis of the amount of reduced methemoglobin and time of incubation.

genotype leads to the formation of a mosaic, with two different cell populations showing both normal and G6PD-deficient red blood cells and with consequent intermediate enzyme activity $6,10,12,15$. To overcome this difficulty, BREWER et al10 supplemented the initial method with quantification of residual methemoglobin by spectrophotometric reading, as recommended by EVELYN \& MALLOY". Using this method, they observed methemoglobin values varying from 5 to $80 \%$ for heterozygotes and up to a maximum of $5 \%$ for non-deficient homozygotes.

The general principle of the method standardized is based on the stimulation of the glucose-6-phosphate dehydrogenase with methylene blue14 after methemoglobin formation by the addition of sodium nitrite ${ }^{10}$. Thus, it is very important to determine the ideal amount of substrate, i.e. of the methemoglobin that will be generated by sodium nitrite. For this purpose we determined the ideal range of methemoglobin reduction by methylene blue in the presence of different sodium nitrite concentrations. It was demonstrated that, the rate of methemoglobin reduction was fast at low sodium nitrite concentrations, while the excess substrate produced at high concentrations made it difficult for the enzyme system to revert methemoglobin. The author's concern was to select a sodium nitrite concentration at which there would be neither lack of substrate nor the oxidative stress observed after $1.2 \mathrm{~g} \%$ concentration. Thus the $0.7 \mathrm{~g} \%$ sodium nitrite concentration was selected because it was on the ascending line of the methemoglobin reduction curve, because it reduced methemoglobin at a rate located between the maximum and minimum values, and because it lay outside the range of oxidative stress, thus causing less damage to the enzyme systems of the erythrocytes.

The ideal time of incubation was selected on the basis of the kinetic study using whole blood and washed red cells. Greater substrate formation by sodium nitrite and greater methemoglobin reduction by methylene blue were observed when washed red cells were used. However, the reaction stabilized at 90 minutes of incubation both for whole blood and for washed red cells.

Analysis of the results permitted us to propose that plasma had an obvius effect on the amount of methemoglobin formed by sodium nitrite. The differences observed may be atributed to possible reactions of sodium nitrite with plasma substances. The same was observed when the results obtained with whole blood and washed red cells were compared in terms of methemoglobin reduction by methylene blue.

BREWER et al ${ }^{10}$ used whole blood, 1.25 $\mathrm{g} \%$ sodium nitrite concentration and 180 minutes of incubation. In the present study, the use of washed red cells on the one hand permitted the formation of a larger amount of methemoglobin by sodium nitrite and on the other permitted a decrease in incubation time, also showing that there was no sex difference in methemoglobin reduction by methylene blue. These results permit us to conclude that sodium nitrite and methylene blue interact more easily with red blood cells in the absence of plasma.

Finally, it should be pointed out that this new method uses a sodium nitrite concentration lying outside the range of oxidative strees, shortens incubation time to 90 minutes and avoids the influence of plasma employing washed red cells.

The methods used to study glutathione reductase activity in vitro are quite complex and expensive $12,16,17$. Thus, one of the objectives of the present study was to standardize a new, 
BARRAVIERA, B.; MACHADO, P.E. de A.; MEIRA, D.A.; CURI, P.R.; MARTINS, J.N.P. \& SOUZA, J.M. de - Glucose-6-phosphate dehydrogenase and glutathione reductase activity in methemoglobin reduction by methylene blue and cystamine. Study on glucose-6-phosphate dehydrogenase-deficient individuals, on normal subjects and on riboflavin-treated subjects. Rev. Inst. Med. trop. São Paulo, 30(5):370-378, 1988

inexpensive method that could be applied to field studies ${ }^{4}$ in order to determine the activity of this enzyme. The glutathione reductasestimulating agent used for this purpose was cystamine, which can oxidize reduced glutathione in vitro, with the latter in turn acting as a substrate for glutathione reductase ${ }^{x, 9}$. When oxidized glutathione is reduced by glutathione reductase, methemoglobin is simultaneously reduced to hemoglobin. Thus, glutathione reductase activity was evaluated on the basis of the amount of methemoglobin metabolized. It was important to determine the cystamine concentration that would permit ideal interaction between substrate and enzyme. Another important factor was the evaluation of the ideal time of incubation. Thus, the method was standardized at $0.1 \mathrm{M}$ cystamine concentration and at the shortest time of incubation, i.e. 180 minutes.

Comparison of the results obiained by the two niethods permitted us to conclude that methylene blue is about three times as effective as cylamine in reducing methemogiobin, a difference due to the greater capacity of methylene blue to stimulate glucose-6-phospiate dehydresenaseti2. It should be poinied out, Marer hat he pathways studied are ditferen i.e. methyiene blue stimulates the G6PD by NADPH oxidation 6.10.12.15, while cystamine acts through the glutathione reductase system by oxidizing the reduced glutathone, These observations permit us to conclude that cystamine is capable of reducing methemoglobin to hemoglobin by the indirect action of glutathione reductase, and to postulate that the reaction occurring within the erythrocytes follows the scheme indicated in figure 4 .

The standardized methods were applied to a sample of the population of Anhembi (State of São Paulo). Two non-G6PD-deficient individuals were detected, who, however, did not reduce methemoglobin in the presence of cystamine. These subjects, adult females, were treated with riboflavin. No difference in methemoglobin reduction by methylene blue was observed before and after treatment. However, methemoglobin reduction by cystamine increased after riboflavin treatment. demonstrating that stimulation of glutathione reductase activity to be complete, ideal amounts of FAD, a riboflavin derivative, are

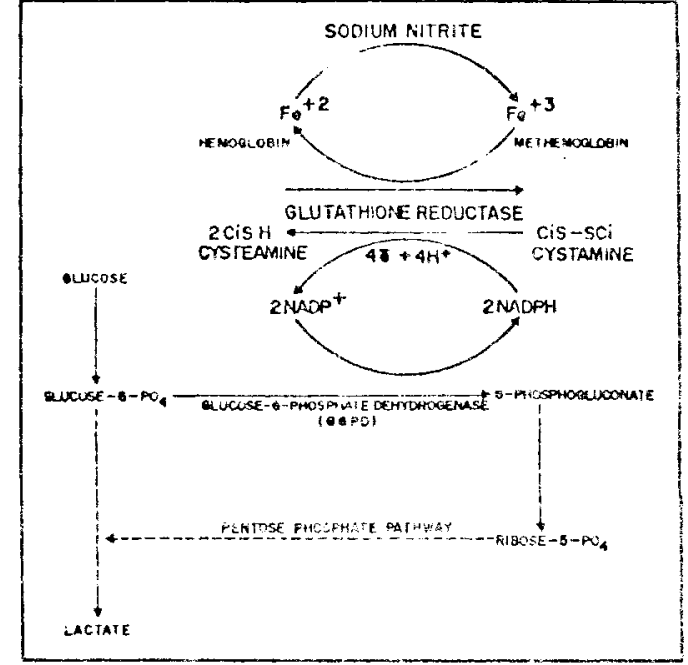

Fig. + - Schematic presenaton of mothemogiobn reduction to hemoglobin by cystamine through the indires: actiun of glitathone reductase

needed $5,6,12,16,17$. On the other hand, hereditary glutathione reductase deficiency is quite rares.12, although deficiency of the FAD ccenzyme, which acts together with glutathione reductase, is frequent $4,5,6,16,17$. On this basis, the two women who did not reduce methemoglobin by cystamine had glutathione reductase deficiency not because of hereditary absence of the enzyme, but because of FAD coenzyme deficiency.

To confirm the results observed, individuals females. were treated with riboflavin. No change in hematocrit or hemoglobin levels was detected after treatment, but the amount of methemoglobin formed by sodium nitrite was greater after treatment with the vitamin and the reduction of methemoglobin by cystamine increased significantly, suggesting that glutathione reductase was stimulated. These results permit us to conclude that treatment with riboflavin of normal individuals, i.e. individuals who reduce methemoglobin by cystamine, can increase glutathione reductase activity.

Finally, three Black G6PD-deficient individuals were studied. After stimulation of the G6PD with methylene blue, the males showed less methemoglobin reduction than 
BARRAVIERA, B.; MACHADO, P.E. de A.; MEIRA, D.A.; CURI, P.R.; MARTINS, J.N.P. \& SOUZA, J.M. de - Glucose-6-phosphate dehydrogenase and glutathione reductase activity in methemoglobin reduction by methylene blue and cystamine. Study on glucose-6-phosphate dehydrogenase-deficient individuals, on normal subjects and on riboflavin-treated subjects. Rev. Inst. Med. trop. São Paulo, 30(5):370-378, 1988.

normal individuals. This difference may be explained by the lack of response to methylene blue stimulation in G6PD-deficient individuals $6,10,12$. When glutathione reductase was stimulated with cystamine, methemoglobin reduction was also less than in normal individuals. Thus, in these individuals neither methylene blue nor cystamine induced adequate methemoglobin reduction. The G6PD-deficient female showed less than normal methemoglobin reduction by methylene blue, but higher than observed in the G6PD-deficient males. Thus, being a female, she behaved in a heterozygous manner for G6PD deficiency. In view od the race and laboratory characteristics of these individuals, it is suggested that their G6PD deficiency is of the African type.

Glutathione reductase was partially activated in these individuals, with methemoglobin reduction similar to that observed in the two non-G6PD-deficient individuals from Anhembi, who, however, were glutathione reductase-deficient. The data suggest that glutathione reductase activity is dependent on NADPH generation by the pentose pathway. However, the latter may be functioning in an adequate manner, while glutathione reductase activity is decreased. Other factors, the need for the FAD coenzyme among them, are necessary for the full functioning of glutathione reductase.

These results agree with those of PRENTICE et al18, who detected a positive correlation between glutathione reductase activity and G6PD activity. On the other hand, decreased glutathione reductase activity has been detected in G6PD-deficient individuals ${ }^{18,20}$.

Finally, analysis of the results as a whole permits us to conclude that cystamine was able to reduce methemoglobin to hemoglobin by the action of glutathione reductase, which in turn depends on the NADPH-generating pentose pathway. In addition, an adequate supply of riboflavin is needed for the full functioning of glutathione reductase $5,6,7,12,16,17,18,20,21$. Thus, the methods proposed here proved to be effective for the evaluation of G6PD and of glutathione reductase, and for the indirect determination of riboflavin deficiency.

\section{RESUMO}

Atividade da glicose-6-fosfato desidrogenase e glutationa redutase na redução da metahemoglobina pelo azul de metileno e cistamina. Estudo em indivíduos deficientes em glicose-6-fosfato desidrogenase, normais e tratados pela riboflavina.

Os autores padronizaram métodos para a avaliação da atividade da glicose-6-fosfato desidrogenase e glutationa redutase. O princípio geral do primeiro método baseou-se na formação de metahemoglobina pelo nitrito de sódio, seguido da estimulação da via das pentoses pelo azul de metileno. Foram estudados 46 individuos adultos, sendo 23 do sexo masculino e 23 do feminino, não deficientes em glicose-6fosfato desidrogenase (G6PD), com idades variando entre 20 e 30 anos. Os resultados revelaram que a redução da metahemoglobina pelo azul de metileno para sangue total, foram de 154.50 e $139.90 \mu \mathrm{g} / \mathrm{min}(\mathrm{p}<0.05)$ respectivamente para o sexo masculino e feminino. Para hemácias lavadas os valores foram de $221.10 \mathrm{e}$ $207.85 \mu \mathrm{g} / \mathrm{min}$ (n.s.) respectivamente. Estas observações permitiram concluir que ao se empregar hemácias lavadas e $0.7 \mathrm{~g} \%$ de concentração de nitrito de sódio, por um lado não houve diferença entre os sexos e por outro, abreviou o tempo de leitura da quantidade residual de metahemoglobina para 90 minutos.

A avaliação da atividade da glutationa redutase foi feita baseado no fato de que a cistamina (agente tiol) liga-se aos grupos $\mathrm{SH}$ da hemoglobina formando complexos. Estes complexos são revertidos pela ação da glutationa redutase, ocorrendo conjuntamente nesta reação a redução da metahemoglobina. Foram estudados 32 indivíduos adultos, sendo 16 do sexo masculino e 16 do feminino, não deficientes em G6PD, com idades variando entre 20 e 30 anos. Os resultados revelaram valores de redução da metahemoglobina pela cistamina de 81.27 e $91.13 \mu \mathrm{g} / \mathrm{min}(\mathrm{p}<0.01)$ respectivamente para $\mathrm{o}$ sexo masculino e feminino. Estas observações permitiram concluir que o emprego de hemácias lavadas e 0.1 molar de concentração de cistamina torna possivel a leitura da quantidade residual de metahemoglobina aos 180 minutos de incubação.

A atividade da glutationa redutase avaliada por meio da redução da metahemoglobina pela cistamina, foi estudada em 14 indivíduos 
BARRAVIERA, B.; MACHADO, P.E. de A.; MEIRA, D.A.; CURI, P.R.; MARTINS, J.N.P. \& SOUZA, J.M. de - Glucose-6-phosphate dehydrogenase and glutathione reductase activity in methemoglobin reduction by methylene blue and cystamine. Study on glucose-6-phosphate dehydrogenase-deficient individuals, on normal subjects and on riboflavin-treated subjects. Rev. Inst. Med. trop. São Paulo, 30(5):370-378, 1988.

do sexo feminino antes e após o tratamento com $10 \mathrm{mg}$ por dia de riboflavina durante 8 dias. Os resultados foram de 73.69 e 94.26 $4 \mathrm{~g} / \mathrm{min}(\mathrm{p}<0.01)$ antes e após o tratamento. Estas observações permitiram concluir que a oferta de riboflavina, mesmo para individuos normais, aumenta a atividade da glutationa redutase. Foram ainda avaliados 3 indivíduos da raça negra e deficientes em G6PD, sendo 2 do sexo masculino e 1 do feminino. Houve ativação parcial da G6PD e glutationa redutase, sendo estas alterações mais intensas nos indivíduos do sexo masculino. Considerando-se a raça e as características laboratoriais observadas, foi possivel sugerir que a deficiência em G6PD verificada é do tipo Africano, bem como, permitiu considerar os individuos do sexo feminino como sendo heterozigoto para esta deficiência.

Por fim, a análise dos resultados em seu conjunto permitiu concluir que os metodos propostos se mostraram eficientes para avaliar a atividade da G6PD e glutationa redutase. Esta ultima é ciependente da via das pentoses, geradora de $N A D P H$ a da ribofiavina, vilamina precursora de FAD.

\section{REFERENCES}

BARRAYIRA, H. - Malária causada pelo Plasmodium talciparum e a redução da metahemoglobina pela via das pentoses. Botucatu, 1984. (Dissertação de mestrado - Faculdade de Medicina de Botucatu da Universidade Estadual Paulista "Júlio de Mesquita Filho")

2. BARRAVIERA, B. - Malária causada pelo Plasmodium falciparum e avaliação indireta da atividade da glutationa redutase e da deficiência de riboflavina, por meio da reducão da metahemoglobina pela cistamina. Botucatu, 1986 (Tese de doutoramento - Faculdade de Medicina de Botucatu da Universidade Estadual Paulista "Júlio de Mesquita Filho")

3. BARRAVIERA, B.; MEIRA, D.A.; MACHADO, P.E.A. \& CURI, P.R. - Malária no municipio de Humaitá, Estado do Amazonas. XXI. Prevalência da deficiência de glicose-6-fosfato desidrogenase (G6PD) em amostra da populaçâo e em doentes com malária causada pelo Plasmodium falciparum. Rev. Inst. Med. trop. S. Paulo, 29:374-380, 1987.

4. BARRAVIERA, B.; MACHADO, P.E.A. \& MEIRA, D.A. - Glutathion reductase activity and its relation with riboflavin levels measured by methemoglobin reduction by cystamine in patients with malaria (Preliminary report). Rev. Inst. Med. trop. S. Paulo, 30: $107-108,1988$.

5. BATES, C.J.; PRENTICE, A.M.; PAUL, A.A.; PRENTICE, A.; SUTCLIFFE. A. \& WHITEHEAD, R.G. - Riboflavin status in infants born in rural Gambia, and the effect of a weaning food supplement Trans, roy. Soc. trop. Med. Hyg., 76:253-258, 1982.

6. BEUTLER, E. - Deficiência de glicose-6-fosfato desidrogenase. In: STANBURY, J.B.; WYNGAARDEN,
J.B. \& FREDRICKSON, D.S. - Bases metabólicas das doenças hereditárias. 4. ed. Rio de Janeiro, Guanabara Koogan, 1981. p. 1485-1506.

7. BEUTLER, E. \& SRIVASTAVA, S.K. Relationships between glutathione reductase activity and drug-induced haemolytic anaemia. Nature, 226:759-760, 1970.

8. BEUZARD, Y.; MACHADO, P.E.A.; HASSAN, W.; MAX-AUDIT, I.; GAREL, M.C. \& ROSA, J. Inhibition of sicking by cystamine. In: CAUGHEY, W.S., ed. - Biochemical and clinical aspects of hemoglohin abnormalities. New York, Academic Press, 1978. p.237-250.

9. BEUZARD, Y.; ROSA, J.; MACHADO, P.E.A. HASSAN, W.; MAX-AUDIT, I.\& GAREL, M.C. Anticickling effect of cystamine and its action on the biosynthesis of hemoglobin. In: BREWER, G.J., ed. - Progress in clinical and biological research. New York, A.R. Liss, 1977. p.109-128.

10. BREWER, G.J.; TARLOV, A.R. \& ALVING, A.S Methaemoglobin reduction test. A new simple, in vitro test for identifying primaquine-sensitivity. Bull. Wid Hith. Org., 22:633-640, 1960.

11. EVELYN, K.A. \& MALLOY, H.T. Micro determination of oxyhemoglobin, metnemoglobin, and sulfemoglobin in a single sample of blood. J. hio: Chem., 126:655-662, 1938.

12. GRIMES, A.J. - Human sed cell metabolism. London, Blackwell, 1980.3840 .

13. MANDULA, B. \& BEUTLER, E. - Syrthesis of ribotlavin nucleotides by nature human erythrocytes. Blood, 36:491-499, 1970.

14. METZ, E.N.; BALCERZAK, S.P. \& SAGONE JR. A.L. - Mechanisms of methylene blue stimulation of the hexose monophosphate shunt in erythrocytes. $J$. clin. Invest., 58:797-802, 1976.

15. ORGANIZACIÓN MUNDIAL DE LA SALUD Normalización de las técnicas de estudio de la glucosa6-fosfato deshidrogenasa. Org. mund. Salud. Ser. Inf. técn., (366): 1-257, 1967.

16. PRENTICE, A.M. \& BATES, C.J. - A biochemical evaluation of the erythrocyte glutathione reductase (EC 1.6.4.2) test for riboflavin status. Brit. J. Nutr., 45:37$52,1981 \mathrm{a}$.

17. PRENTICE, A.M. \& BATES, C.J. - A biochemical evaluation of the erythrocyte glutathione reductase (EC.1.6.4.2) test for riboflavin status. 2. Doseresponse relationships in chronic marginal deficiency. Brit. J. Nutr., 45:53-65, 1981 b.

18. PRENTICE, A.M.; BATES, C.J.; PRENTICE, A.; WELCH, S.G.; WILLIAMS, K. \& MCGREGOR, J.A - The influence of G6PD activity on the response of erythrocyte glutathione reductase to riboflavin deficiency. Int. J. vit. Nutr. Res., 51:211-215, 1981.

19. RIVLIN, R.S. - Riboflavin metabolism. New Engl. J. Med, 283:463-472, 1970.

20. SWARUP-MITRA, S. - Activity of glutathione peroxidase and glutathione reductase in G6PD deficient subjects. Indian J. med. Res., 66:253-259, 1977.

21. THURNHAM, D.I. - Influence of glucose-6phosphate dehydrogenase deficiesicy on the glutathione reductase test for ariboflavirosis. Ann. trop. Med. Parasit., 66:505-508, 1972.

Recebido para publicaçz̃o em 12/5/1988. 